\title{
Soil Microbial Community Analysis using Soil Enzyme Activities in Red Pepper Field Treated Microbial Agents
}

\author{
Yo-Hwan Kim $\cdot$ Jong-Hui Lim $\cdot$ Chang-Hwan An $\cdot$ Byung-Kwon Jung $\cdot$ \\ Sang-Dal Kim

\section{토양효소활성을 이용한 미생물제제 처리 고추경작지의 토양미생물군집 분석}

김요환 · 임종희 · 안창환 · 정병권 · 김상달

Received: 21 October 2011 / Accepted: 2 February 2012 / Published Online: 31 March 2012

(C) The Korean Society for Applied Biological Chemistry 2012

\begin{abstract}
Increasing concerns over green farming technology, plant growth promoting rhizobacterium (PGRP) having growth promoting as well as plant disease suppressing properties was recently preferred to use for biological control of plant pathogens infecting plant. We measured the influence of the selected microbial consortium agents-a mixture of PGPR strains-, commercial biofungicide, and chemical pesticides on soil microbial community in red pepper field. The activities of soil enzyme such as dehydrogenase, urease, phosphatase, $\beta$-glucosidase, and cellulase were analyzed to investigate that of soil microbial community. We also measured plant length, main stem, stem diameter, number of branches and yields of red-pepper in order to observe the red pepper growth promotion. The results of measuring enzyme activities were

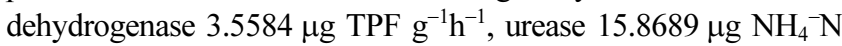
$\mathrm{g}^{-1} \mathrm{~h}^{-1}$, phosphatase $0.5692 \mu \mathrm{g}$ PNP g ${ }^{-1} \mathrm{~h}^{-1}, \beta$-glucosidase $2.4785 \mu \mathrm{g}$ PNP g ${ }^{-1} \mathrm{~h}^{-1}$, and cellulase $86.1597 \mu \mathrm{g}$ glucose $\mathrm{g}^{-1} \mathrm{~h}^{-1}$ in the soil treated with the microbial consortium agents, so it came out to be very active in the soil. Observing the growth of red-peppers, the main-stem length and the stem diameter were $6.1 \%$ and $8.1 \%$ higher in the soil treated with the selected microbial consortium agent than the chemical pesticides. After harvesting, yields were $7.3 \%$ higher in the soil treated with selected microbial consortium agents than the chemical pesticides. These results showed that microbial consortium agents contribute to increasing soil microbial diversity, growth promoting, and yield of red pepper.
\end{abstract}

Y.-H. Kim · J.-H. Lim · C.-H. An · B.-K. Jung · S.-D. Kim $(\varangle)$ Department of Microbial Biotechnology, School of Biotechnology, Yeungnam University, Gyeongsan, Gyeongbuk 712-749, Republic of Korea

E-mail: sdkim@ynu.ac.kr
Keywords plant growth promoting rhizobacterium . soil enzyme $\cdot$ soil microbial community

\section{서 론}

친환경적 농법이 대두되면서 길항미생물을 이용한 생물학적 식 물병 방제가 선호되고 있고(Pusey, 1996; Park 등, 2009), 이를 미생물제제로 활용한 미생물농법이 많은 농가에 보급되어 사용 되고 있다(Lee와 Kim, 2000; Lee 등, 2003; Jung 등, 2005; Kang 등, 2005). 최근에는 식물병원균에 대한 길항능과 식물생 장촉진능을 동시에 가지는 plant growth promoting rhizobacterium (PGPR) 균주에 대한 연구가 활발히 진행되고 있다(Jung 등, 2006; 2007). PGPR은 식물뿌리주변에 서식하는 근권미생물로서 식물병원성 진균의 세포벽을 분해하는 용균작용 $(\mathrm{Lim}$ 과 $\mathrm{Kim}$, 1995; Han 등, 1999; Yun 등, 2001), Bacillus sp., Pseudomonas $\mathrm{sp}$.등이 생산하는 항생물질에 의해 식물병원성 진균의 생육을 저해하는 항생작용 $(\mathrm{Kim}$ 과 $\mathrm{Kim}, 1997$; Jeong 등, 2004; Jung 과 $\mathrm{Kim}, 2004)$ 등과 같은 길항능과, 식물과의 상호작용을 통한 식물생장촉진능 $(\operatorname{Lim}$ 등, 2009)을 가진다. PGPR 균주의 식물병 억제효과와 식물생장촉진능을 동시에 발휘하게하기 위해선 식 물병 억제와 생장촉진 효과가 필요한 기간만큼 지속적으로 토 양에서 살아남아야 하지만, 토양에 접종된 미생물은 짧은 시간 내에 그 수가 줄어들고, 토양미생물 군락도 원래의 상태대로 복 원된다(Van Veen 등, 1997; Thirup 등, 2003; Park 등, 2009). 단기간에 밀도가 감소되긴 하지만 PGPR 균주를 지속적으로 투 입했을 경우 토양미생물의 다양성과 생태에 미치는 영향은 예 측하기 어렵다.

토양미생물군집의 생태를 분석하기 위한 방법 중 토양효소 
활성도 측정은 토양비옥도를 반영하여 토양질의 중요한 생물지 표가 되는데(Paul과 Clark, 1989; Anderson, 1991; Kirschbaum, 1995; Nobili 등, 2006; $\mathrm{Hu}$ 와 Cao, 2007; Koch 등, 2007), 주변 환경 여건에 따라 토양미생물의 상대적 활력도가 달라지 므로 특정 효소활성을 측정함으로써 토양미생물의 상대적 활성 을 측정하고 이를 기준으로 토양생태계의 건전성을 평가할 수 있다(Speir 등, 1999; Chew 등, 2001; Langer와 Günther, 2001). 그 중 dehydrogenase는 토양호흡의 지수로 사용되고 (Garcia 와 Hernandez, 1997), urease는 토양 내 미생물들이 이 용할 수 있는 질소원을 공급하는 역할을 한다(Garcia-Gil 등, 2000). 그리고 phosphatase는 토양 내 유기인산을 분해하여 가 용화(mineralization)함으로써 미생물들이 이용할 수 있도록 해 주고(Garcia-Gil 등, 2000), $\beta$-glucosidase는 유기물내의 다당류 를 분해하여 포도당으로 전환시켜 미생물들에 공급하며(Eivazi 와 Tabatabai, 1988), cellulase는 식물 잔류물 분해에 중요한 효 소이다(Rai와 Srivastava, 1983). 토양효소활성의 측정을 이용해 특정지역 토양의 미생물상을 관찰하거나(Choi, 2003) 토양생태 계의 건전성을 측정하는 연구는 보고된 바 있으나(Baek, 2003) 미생물제제와 화학농약을 처리한 토양의 미생물상을 비교분석 하여 토양미생물상의 변화와 작물의 생장에 끼치는 영향을 분 석한 연구는 많지 않다.

따라서 본 연구는 길항미생물을 이용하여 최적 컨소시엄제제 로 이미 개발된( $\operatorname{Lim}$ 등, 2009) 복합미생물제제의 토양미생물생 태 변화를 토양효소 활성도 측정으로 확인하고자 하였으며, 대 조구로 시판중인 미생물농약과 화학농약을 처리한 고추경작지 에서의 토양효소활성 비교분석을 통해 메타지노믹스를 이용한 토양미생물 다양성 연구의 기본연구자료로 사용하고, 고추의 생 장과 수확량 측정을 통해 미생물의 처리가 작물에 미치는 효과 를 확인하고자 수행되었다.

\section{재료 및 방법}

고추경작지 미생물제제 및 화학농약 처리. 경북 성주군 화성육 묘장에서 고추(Capsicum annuum L.)의 청양품종 800주를 분양 받아 경북 경산시 대동에 위치한 영남대학교 자연자원대학 소 속의 실습포장 $(23 \mathrm{~m} \times 33 \mathrm{~m})$ 에 정식하였다. 처리구로는 물만 처 리한 무처리구와 복합미생물제제(이하 B.B.P), 시판중인 미생물 농약 $(\mathrm{A}$ 사 $\mathrm{B}$, 이하 $\mathrm{AC}-1)$, 시판중인 화학농약 $(\mathrm{C}$ 사 $\mathrm{D}$ 제품, 이하 $\mathrm{LDM})$ 을 선정하여 처리구당 200 주의 고추를 사용하였고, 1 반복 당 50주씩 4회 반복하였다. 복합미생물제제는 PGPR 균주로서 식물생장촉진능과 역병방제능이 있는 Bacillus subtilis $\mathrm{AH} 18$ (Jung 등, 2006), Bacillus licheniformis K11 (Jung 등, 2007)과 Pseudomonas fluorescens 2112 (Lee와 Kim, 2000)를 조합하여 사용하였다( $\operatorname{Lim}$ 등, 2009). 복합미생물제제와 미생물농약은 $10^{6}$ $\mathrm{CFU} / \mathrm{mL}$ 의 농도로, 화학농약은 생산회사의 권장사용농도에 맞 춰 관주시설을 이용하여 한주당 $100 \mathrm{~mL}$ 씩 열흘간격으로 6개월 동안 처리하였다.

토양시료의 채취. 고추를 정식한 7월부터 12월까지 6개월동안 한 달 간격으로 처리구별 토양시료를 채취하였다. 토양샘플의 대표성을 높이기 위해 처리구별로 각 고랑당 $10 \mathrm{~m}$ 간격으로 세 지점에서 멸균한 모종삽을 이용하여 표면의 흙을 $2 \mathrm{~cm}$ 가량 걷 어내고 지면으로부터 약 $30 \mathrm{~cm}$ 깊이까지의 근권토양을 $500 \mathrm{~g}$ 채취한 후 $2 \mathrm{~mm}$ 표준체(10 mesh)로 체거름하여 각 처리구별로
여섯 개의 토양시료를 모아 하나의 시료로 하였다. 이와같이 채 취한 토양시료는 지퍼백에 담아 밀봉하여 4에서 냉장보관하였 고, 장기보관을 위해 $-20^{\circ} \mathrm{C}$ 에 냉동저장 하였다.

Dehydrogenase의 측정. Dehydrogenase는 토양시료 $1 \mathrm{~g}$ 에 0.25 $\mathrm{M}$ Tris buffer ( $\mathrm{pH}$ 7.6) $1 \mathrm{~mL}$ 를 넣고, $1 \%$ glucose $50 \mu \mathrm{L}$ 와 $0.4 \%$ triphenyltetrazolium chloride (TTC)를 $0.2 \mathrm{~mL}$ 넣은 후 $30^{\circ} \mathrm{C}$ 에서 6 시간동안 어두운 곳에 유지하고 6시간 후 메탄올을 $10 \mathrm{~mL}$ 첨가해서 1 분간 잘 섞은 후 여과하여 표준용액과 함께 흡광도 측정기로 $485 \mathrm{~nm}$ 에서 대조구로 멸균한 토양을 위와 동 일한 과정을 통해 triphenyl formazan을 추출하였다. 반응산물의 정량은 $485 \mathrm{~nm}$ 에서 나타나는 흡광도로 측정하였고 효소활성도 는 triphenyl formazan (TPF) $\mu \mathrm{g} \mathrm{g}^{-1} \mathrm{day}^{-1}$ 로 나타내었다(Ross, 1970; Trevors 등, 1982; Trevors, 1984).

Urease의 측정. Urease는 토양 $5 \mathrm{~g}$ 에 $20 \mathrm{~mL}$ 의 Borate buffer (0.1 M, pH 10.0)을 넣고 $2.5 \mathrm{~mL}$ 의 $720 \mathrm{mM}$ Urea용액을 가하 여 밀봉한 상태로 $37^{\circ} \mathrm{C}$ 에서 2 시간동안 배양 후 $2 \mathrm{M} \mathrm{KCl}$ 용액 $30 \mathrm{~mL}$ 를 가하고 30 분간 진탕 후 여과하는데, 배양 현탁액을 여 과하기 직전에 대조구에 $2.5 \mathrm{~mL}$ 의 $720 \mathrm{mM}$ Urea용액과 $2 \mathrm{M}$ $\mathrm{KCl}$ 용액 $30 \mathrm{~mL}$ 를 가하고 30 분간 진탕 후 여과하였다. 여과 후 Sodium salicylate/Soudium hydroxide 혼합액 $5 \mathrm{~mL}$ 와 39.1 $\mathrm{mM}$ Sodium dichloroisocyanide $2 \mathrm{~mL}$ 를 섞어주고 UV-Visible Spectrophotometer를 이용하여 $660 \mathrm{~nm}$ 에서 흡광도를 측정해 처 리구와 대조구의 차로 효소활성을 측정하였다(Joa 등, 2009).

Phosphatase의 측정. Phosphatase는 토양 $1 \mathrm{~g}$ 에 $0.2 \mathrm{~mL}$ 의 toluene을 첨가한 후 $1 \mathrm{~mL}$ 의 $0.025 \mathrm{M} p$-nitrophenyl phosphate $(p$-NPP)와 $4 \mathrm{~mL}$ 의 modified universal buffer $(\mathrm{pH}$ 6.5)를 넣고 혼합. 밀봉하여 $37^{\circ} \mathrm{C}$ 의 항온기에서 1 시간동안 배양 후 $4 \mathrm{~mL}$ 의 $0.5 \mathrm{M} \mathrm{NaOH}$ 와 $1 \mathrm{~mL}$ 의 $0.5 \mathrm{M} \mathrm{CaCl}_{2}$ 를 넣어 잘 섞은다음, 거 름종이로 걸러서 추출된 $p$-nitrophenol을 표준용액과 더불어 400 $\mathrm{nm}$ 에서 흡광도를 측정, 비색 정량하였다(Joa 등, 2008).

$\beta$-glucosidase의 측정. $\beta$-glucosidase는 토양 $1 \mathrm{~g}$ 에 modified universal buffer ( $\mathrm{pH}$ 6.5) $4 \mathrm{~mL}$ 와 $0.025 \mathrm{M}$-nitrophenyl-Dglucopyranoside (PNG) $1 \mathrm{~mL}$ 를 첨가한 후 37에서 1시간 배양 후 $0.5 \mathrm{M} \quad \mathrm{CaCl}_{2} \quad 1 \mathrm{~mL}$ 와 $\quad 0.1 \mathrm{M} \quad \mathrm{THAM}-\mathrm{NaOH} \quad(12.2 \mathrm{~g}$ trishydroxymethlaminomethane, $0.5 \mathrm{M} \mathrm{NaOH}, \mathrm{pH}$ 12.0) $4 \mathrm{~mL}$ 를 첨가해 잘 섞은다음, 용액을 여과하여 $400 \mathrm{~nm}$ 에서 방출된 $p$-nitrophenol의 흡광도를 측정하였다(Joa 등, 2009).

Cellulase의 측정. Cellulase는 토양 $5 \mathrm{~g}$ 을 $50 \mathrm{~mL}$ 삼각플라스크 에 취하고, 톨루엔을 $0.5 \mathrm{~mL}$ 넣어 교반 후 $0.2 \mathrm{M}$ 초산완충액 (pH 5.9) $10 \mathrm{~mL}, 1 \%$ carboxymethylcellulose (CMC) $10 \mathrm{~mL}$ 를 넣고 $30^{\circ} \mathrm{C}$ 에서 24 시간 유지하였다. 동시에 $\mathrm{CMC}$ 대신에 물을 $10 \mathrm{~mL}$ 넣은 것을 대조구로서 똑같이 배양하고, 24시간 후 $50 \mathrm{~mL}$ 의 증류수를 넣고 환원당을 somogyi-nelson법으로 발색해 서 정량하였다(Pancholy와 Rice, 1973).

고추생장촉진능 및 수확량 측정. 평균생육도를 나타내는 고추 10 주를 각 처리구별로 선정해 10 일 간격으로 초장, 주경장, 경 경, 분지수를 측정하였다. 초장은 지면으로부터 작물의 끝까지 총 길이를, 주경장은 지면으로부터 가지가 처음으로 갈라지는 부위까지의 길이를 측정한 것으로 줄자를 이용하여 측정하였 다. 경경은 식물의 굵기로서 지면으로부터 $1 \mathrm{~cm}$ 떨어진 지점에 서 버니어캘리퍼스를 사용하여 측정하였다. 분지수는 식물줄기 가 갈라지는 마디의 수로 처음 갈라지는 하나의 줄기를 선정해 그 줄기의 마지막으로 갈라지는 부분의 개수를 측정하였다. 그 리고 총 다섯 번에 걸쳐 수확한 생고추의 무게를 측정하여 처 
리구별로 그루당 열리는 생고추의 무게를 비교분석하였다.

\section{결과 및 고찰}

토양효소활성을 통한 경작지 토양미생물상 분석. 토양의 건전성 과 토양미생물상을 분석하는 방법으로 dehydrogenase, urease, phosphatase, $\beta$-glucosidase, cellulase등의 지표토양효소 활성도를 측정하여 토양미생물군집과 생태의 변화를 알아보았다. 각 처리 구의 월별 변화추이를 관찰하고자 하였으나 효소활성 변화의 폭 이 일관성 없이 월별로 큰 차이를 보여 선발된 미생물제제와 대조구인 상업용 농약에 의한 변화를 관찰하기가 용이하지 않 았다. 이는 기온에 의한 온도의 변화와 강우에 의한 수분함량 의 변화가 다른 요소들보다 토양효소활성에 더 영향을 미친다 는 보고(Paul과 Clark, 1989; Anderson, 1991; Kirschbaum, 1995; Nobili, 2006; Koch 등, 2007)와 일치하는 것으로, 온도 와 수분함량에 의한 토양효소활성의 변화를 배제하고 처리구에 따른 토양효소활성차이를 관찰하기 위해 동일한 기준값을 적용 하여 6 개월 동안 월별로 분석한 효소활성의 평균값을 비교분석 하였다.

Dehydrogenase 분석. Dehydrogenation은 탄소화합물의 산화과 정이며 토양호흡의 지수로 사용되기 때문에 dehydrogenase의 측 정은 토양 미생물군집의 활성과 토양미생물의 대사활동 수준을 잘 나타내준다(Garcia 와 Hernandez, 1997). 6개월 동안 측정한 dehydrogenase의 수치는 복합미생물제제 B.B.P처리구에서 $3.5584 \mu \mathrm{g} \mathrm{TPF} \mathrm{g}^{-1} \mathrm{~h}^{-1}$ 로 가장 높은 값을 나타내었고, 미생물농 약 $\mathrm{AC}-1$ 처리구가 $3.3463 \mu \mathrm{g} \mathrm{TPF} \mathrm{\textrm {g } ^ { - 1 }} \mathrm{h}^{-1}$, 무처리구가 $2.6081 \mu \mathrm{g}$ $\mathrm{TPF} \mathrm{g}^{-1} \mathrm{~h}^{-1}$, 화학농약 LDM처리구가 $2.4164 \mu \mathrm{g}$ TPF $\mathrm{g}^{-1} \mathrm{~h}^{-1}$ 의 값을 나타내었다. 이와같은 결과는 6 개월 동안 복합미생물제제 와 미생물농약을 지속적으로 처리한 토양에서 토양미생물군집 의 활성과 대사활동이 가장 활발하다는 근거로 미생물의 처리 가 토양미생물상을 더 다양하게하는 효과를 가져다준다고 보여 진다(Fig. 1A).

Urease 분석. Urease는 유기질소의 가용화(mineralization)를 촉 진시켜 토양 내 미생물들이 이용할 수 있는 질소원(주로 암모 니아태질소)을 공급하는 중요한 역할을 수행하는 효소로 urea를 암모니아로 분해한다(Garcia-Gil 등, 2000). 6개월간의 측정에서 복합미생물제제 B.B.P처리구가 $15.8689 \mu \mathrm{g} \mathrm{NH}_{4}{ }^{-} \mathrm{N} \mathrm{g}^{-1} \mathrm{~h}^{-1}$ 로 가 장 높은 수치를 보였고, 미생물농약 $\mathrm{AC}-1$ 처리구가 $15.3195 \mu \mathrm{g}$ $\mathrm{NH}_{4}{ }^{-} \mathrm{N} \mathrm{g}^{-1} \mathrm{~h}^{-1}$, 무처리구 $14.6667 \mu \mathrm{g} \mathrm{NH}_{4}^{-} \mathrm{N} \mathrm{g}^{-1} \mathrm{~h}^{-1}$, 화학농약 $\mathrm{LDM}$ 처리구 $11.9437 \mu \mathrm{g} \mathrm{NH}{ }_{4}^{-} \mathrm{N} \mathrm{g}^{-1} \mathrm{~h}^{-1}$ 를 나타내었다(Fig. 1B). Urease가 암모니아태질소를 공급하는 중요한 역할을 수행함으 로(Garcia-Gil 등, 2000), 복합미생물제제의 처리가 근권토양미 생물들이 이용하는 질소원 공급을 더 원활히 해준다고 생각된다. Phosphatase 분석. Phosphatase는 가수분해효소의 하나로 인산 에스테르 및 인산무수물(폴리인산)의 가수분해를 촉매하는 효소 로서 토양내 유기인산을 분해하여 가용화(mineralization)함으로 써 미생물들이 이용할 수 있도록 도와주는 중요한 역할을 담당 하고 있다(Garcia-Gil 등, 2000; Baek, 2003). Phosphatase는 토양 내 유효인산이 낮을 때 증가하는 경향이 있으며 $\mathrm{Cu}$ 나 $\mathrm{Zn}$ 같은 중금속에 의해 효소활성이 억제되기도 하며 무기인산에 의 해서도 음의 되먹임 작용에 의해 억제되므로 토양 내 유효인의 함량이 효소활성을 좌우하는 중요한 역할을 하고 있는 것으로 알려지고 있다(Garcia-Gil 등, 2000). 모든 처리구가 $1.0 \mu \mathrm{g}$

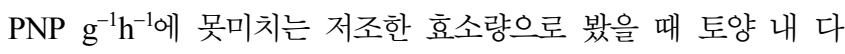
량의 중금속이나 무기인산이 함유되어 있음을 유추할 수 있었 다. 전체적으로 미비한 양이지만 그 가운데 복합미생물제제 B.B.P처리구가 $0.5692 \mu \mathrm{g} \mathrm{PNP} \mathrm{g}{ }^{-1} \mathrm{~h}^{-1}$ 로 가장 높은 활성을 보였 고 화학농약 $\mathrm{LDM}$ 처리구가 $0.5355 \mu \mathrm{g} \mathrm{PNP} \mathrm{\textrm {g } ^ { - 1 }} \mathrm{h}^{-1}$ 로 두 번째로 높은 활성을 나타내었다(Fig. 1C). 무처리구가 화학농약 LDM 처리구보다 phosphatase 활성이 낮은 것은 화학농약에 의해 투 입되는 중금속의 영향보다 근권이 활성화되어 증가된 토양미생 물의 수가 더 많기 때문인 것으로 풀이된다. 이는 효소활성의 변이가 작물생장과 관련이 있다는 보고(Debosz 등, 1999; Sardans 등, 2008)와 일치하고 뒤에서 언급되는 고추의 분지수 와 고추수확량이 이를 뒷받침한다(Fig. 2D와 Fig. 3).

$\beta$-glucosidase 분석. $\beta$-glucosidase는 토양에서 미생물들이 유기 물내의 다당류를 분해하여 유리된 글루코사이드를 분해해서 최 종적으로 포도당으로 전환시켜 미생물들의 영양원이나 에너지 원으로 이용할 수 있게 도와주는 역할을 담당하는 효소이다 (Baek, 2003). 이 효소는 토양 내의 탄화수소의 분해에 있어서 매우 중요한 역할을 담당하고 있으며 이 효소의 가수분해 산물 들은 토양미생물의 중요한 에너지원으로 이용되고 있다고 알려 져 있다(Eivazi 와 Tabatabai, 1988). $\beta$-Glucosidase의 경우 모

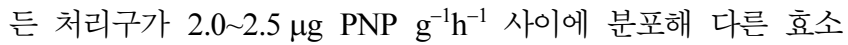
들보다 처리구간의 차이가 크지 않았지만, 복합미생물제제 B.B.P

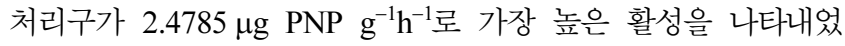
다(Fig. 1D).

Cellulase 분석. Cellulase는 식물체를 구성하는 주요한 탄소화 합물인 cellulose를 분해하는 효소로 이는 식물 잔류물의 분해 에 매우 중요한 대사과정이다(Rai와 Srivastava, 1983). Somogyi - Nelson법으로 환원당을 정량하는 방법으로 측정한 값으로, 복 합미생물제제 B.B.P처리구가 $86.1597 \mu \mathrm{g}$ glucose $\mathrm{g}^{-1} \mathrm{~h}^{-1}$ 로 타 처리구보다 $10.0 \mu \mathrm{g}$ glucose $\mathrm{g}^{-1} \mathrm{~h}^{-1}$ 이상 높게 측정되었다. 무처 리구가 $72.6320 \mu \mathrm{g}$ glucose $\mathrm{g}^{-1} \mathrm{~h}^{-1}$ 으로 두 번째 높은값을 보였 고, 화학농약 $\mathrm{LDM}$ 처리구가 $71.8889 \mu \mathrm{g}$ glucose $\mathrm{g}^{-1} \mathrm{~h}^{-1}$, 미생물 농약 $\mathrm{AC}-1$ 처리구가 $64.7778 \mu \mathrm{g}$ glucose $\mathrm{g}^{-1} \mathrm{~h}^{-1}$ 의 수치를 보여 나머지 처리구에서 cellulase의 수치가 상대적으로 낮게 측정되 었다(Fig. 1E). 따라서, 처리된 복합미생물제제에 의해 토양 내 cellulase 활성이 높아지고 이것은 식물의 잔류분해물의 분해속 도나 양을 증가시켜 결과적으로 토양의 건전성에 긍정적인 영 향을 끼칠 수 있다고 생각할 수 있다.

복합미생물제제의 고추생장촉진능 확인. 미생물제제나 미생물농 약 사용의 목적은 작물의 친환경적 재배와 더불어 농업의 궁극 적인 목표인 재배작물의 생장촉진과 수확량 증대에 있다. 토양 효소활성측정을 통해 복합미생물제제가 토양미생물군집의 활성 에 유익함을 증명하여도 실질적으로 작물재배과정 중 생장과 수 확량에 효과가 없으면 현장에 적용되기 힘들다. 따라서, 복합미 생물제제의 작물에 대한 효과를 입증하기위해 시험작물인 고추 의 초장, 주경장, 경경, 분지수 측정으로 생장을 조사하였다. 초 장과 분지수는 처리구간 큰 차이가 없었지만 주경장과 경경에 서 복합미생물제제 처리구가 생장촉진능을 보였다(Fig. 2). 처리 구별 차이가 미비하였던 초장은 작물의 총 길이로 고추에서는 짧을수록 과실을 맺는데 유리하다(Kwon, 2008). Fig. $2 \mathrm{~A}$ 에서 4 개의 처리구가 $110 \mathrm{~cm}$ 내외로 유사한 초장값을 나타내어 초장 에 의한 생장차이는 없는 것으로 판단된다. 분지수는 갈라지는 마디의 수를 측정한 것으로 그 수가 많을수록 많은 열매를 맺 는다(Kwon, 2008). 분지수는 무처리구를 제외한 세 처리구에서 
A

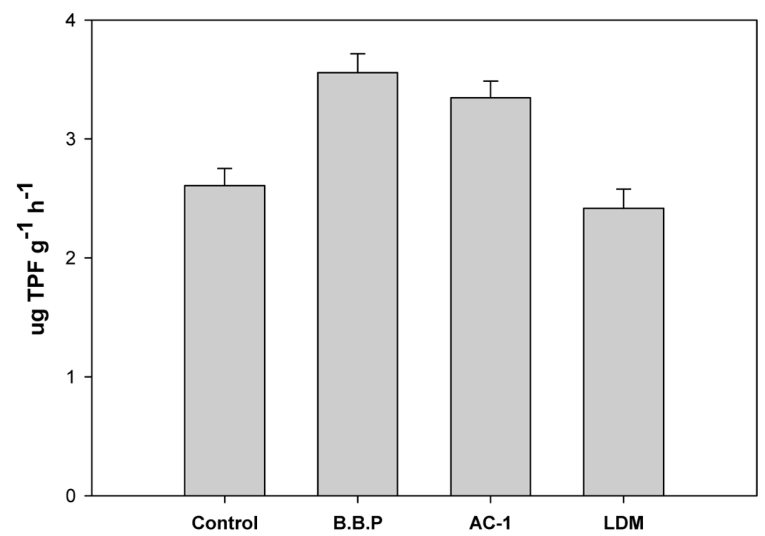

$\mathrm{C}$

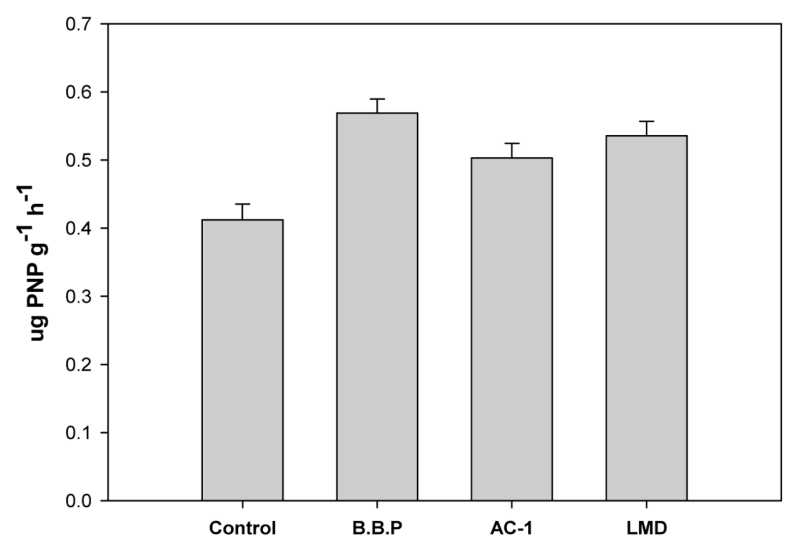

E

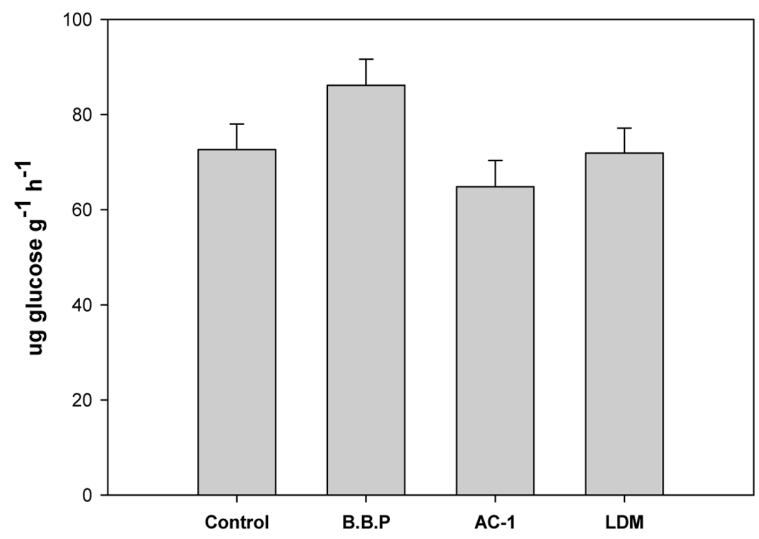

약 14 개의 비슷한 양상을 보였다(Fig. 2D).

위의 두 항목과는 다르게 처리구별로 생육에 차이가 있었던 주경장은 지면으로부터 가지가 처음으로 갈라지는 부위까지의 길이로서 값이 작을수록 맺히는 과실의 수가 증가한다(Kwon, 2008). Fig. 2B에서 나타나는 것처럼 무처리구와 화학농약 처리 구가 $35 \mathrm{~cm}$ 이상을, 복합미생물제제 처리구와 미생물농약 처리 구는 $34 \mathrm{~cm}$ 에 이하의 주경장값을 보였다. 특히 복합미생물제제 처리구는 $33.95 \mathrm{~cm}$ 로 모든 치리구들 중 가장 낮은 주경장값을

\section{B}

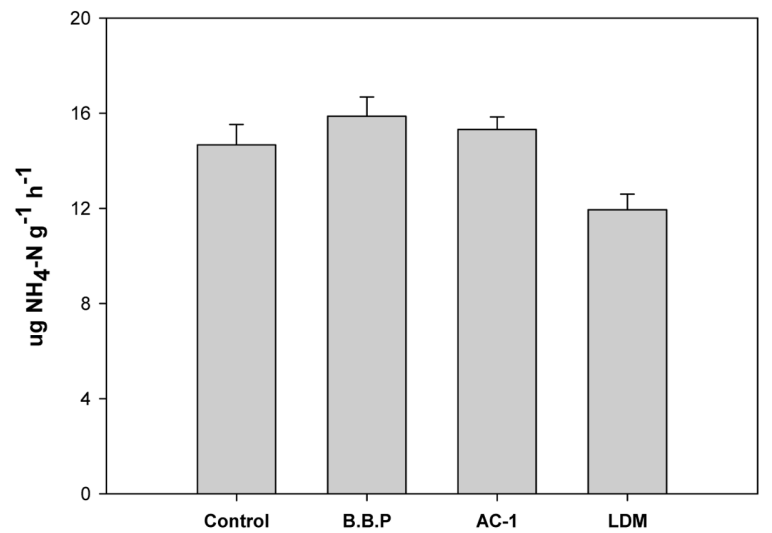

$\mathrm{D}$

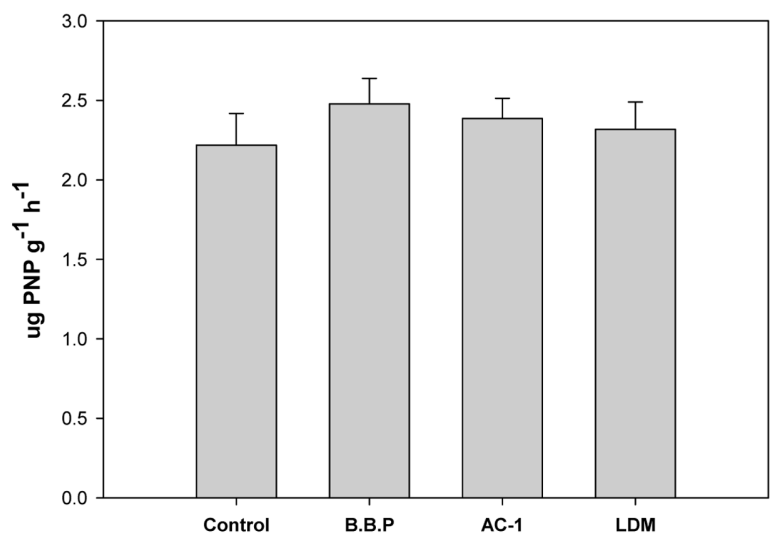

Fig. 1 Soil enzyme activities in the red pepper farming field soil. (A) dehydrogenase; (B) urease; (C) phosphatase; (D) $\beta$-glucosidase; (E) cellulase. Control, only water treatment; B.B.P, new microbial consortium agent; $\mathrm{AC}-1$, commercial bio-fungicide; LDM, chemical pesticide.

나타내었다. 생장초기부터 생장이 끝난 무렵까지 복합미생물제 제와 미생물농약이 지속적으로 적은 생장값을 기록하여 미생물 제제에 의한 생장효과를 입증하였다. 경경은 식물의 굵기로서 값이 클수록 작물의 수확량에 유리한 영향을 미치는 것으로 (Kwon, 2008), 마지막 생장측정인 70일경에 경경의 값이 미생 물농약 처리구와 화학농약 처리구가 $2 \mathrm{~cm}$ 이하의 값을 나타냈 고, 복합미생물제제 처리구가 $2.12 \mathrm{~cm}$ 로 가장 높은값을 나타내 었다(Fig. 2C). 복합미생물제제 처리구가 주경장에서 무처리구 
A

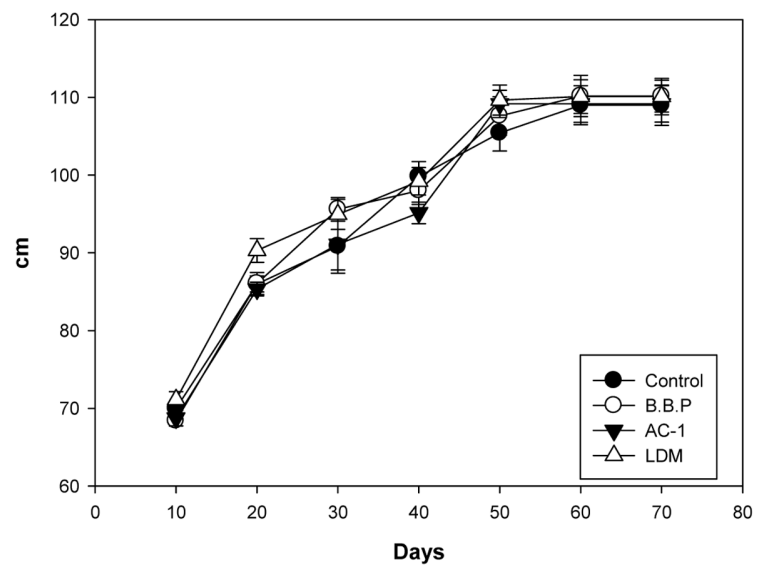

$\mathrm{C}$

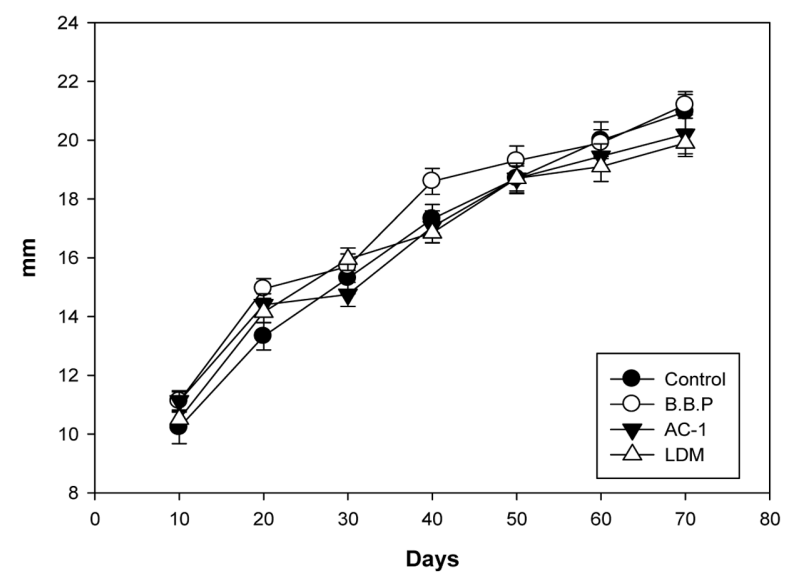

$\mathrm{B}$

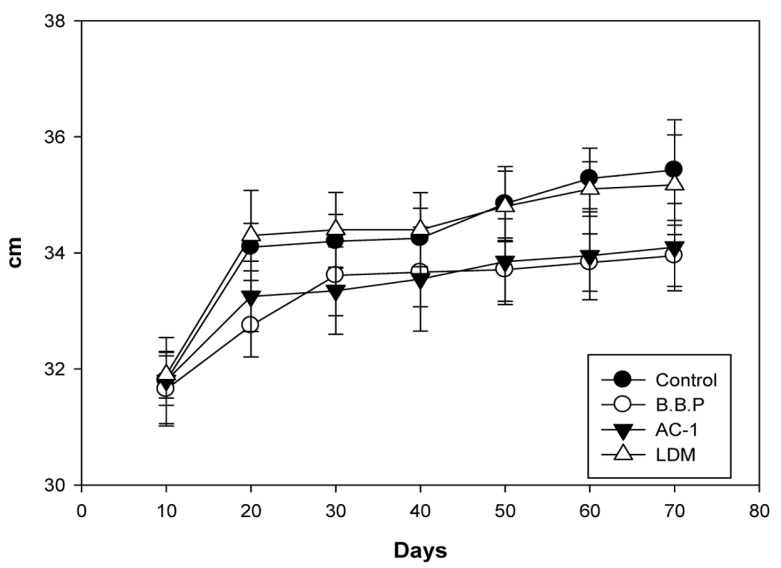

$\mathrm{D}$

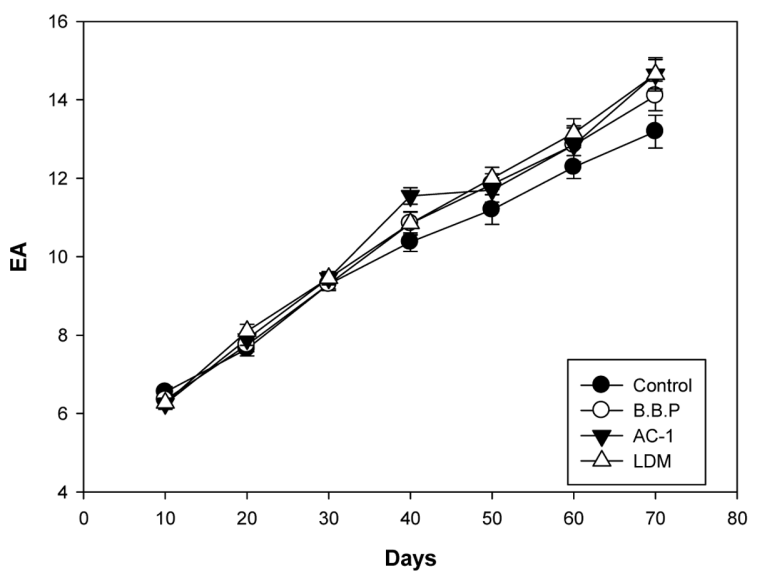

Fig. 2 Growth promotion by the microbial consortium agent on red-pepper. (A) plant length; (B) main stem; (C) stem diameter; (D) number of branches. Plant length, the length from the tip to the surface of plant; main stem, come first or central stem; stem diameter, the thickness of the plant stem. Commercial bio-fungicide and PGPR consortium was treated $10^{6}$ cells per plant. Values are expressed as the means of four replicates, each containing 50 plants. Control (- -), only water treatment; B.B.P (- $\bigcirc-)$, new microbial consortium agent; AC-1 (- $\mathbf{-}$-), commercial bio-fungicide; $\operatorname{LDM}(-\triangle-)$, chemical pesticide.

보다 $6.1 \%$, 경경에서 화학농약 처리구보다 $8.1 \%$ 의 생장촉진능 을 보인 것은 본 연구에 사용된 PGPR 균주들의 생장촉진능을 밝혀낸 $\operatorname{Lim}$ 등(2009)의 연구와 일치하는 것으로 복합미생물제 제의 사용이 토양미생물상의 다양성 증가와 함께 토양과 고추 의 생장향상 모두에 기여했다고 판단된다.

복합미생물제제에 의한 고추의 수확량 증대효과. 수확량은 총 다섯 번 수확한 생고추의 평균값으로 각 처리구의 전체 무게에 서 작물의 총 그루수를 나눠 작물 한 그루당 수확한 고추의 무 게를 비교하였다. 복합미생물제제 처리구가 그루당 $310 \mathrm{~g}$ 으로 가장 높은값을 보였고, 화학농약 처리구는 그루당 $289 \mathrm{~g}$, 미생 물농약 처리구는 그루당 $270 \mathrm{~g}$, 무처리구는 그루당 $269 \mathrm{~g}$ 의 수 확량을 나타내었다. 무처리구를 기준으로 복합미생물제제 처리 구는 $15 \%$ 증가하였고, 화학농약 처리구는 $7 \%$ 증가, 미생물농 약 처리구는 $1 \%$ 증가함을 보여 타 처리구들에 비해 복합미생 물제제 처리구가 두 배 이상의 증대효과가 나타났다(Fig. 3).

복합미생물제제 균주에 의한 수확량 증대효과의 결과는 본 연구에 사용된 PGPR 균주들의 생장촉진능을 밝혀낸 $\mathrm{Lim}$ 등
(2009)의 보고와 일치하고, 토양효소활성분석을 통해 복합미생 물제제의 토양미생물상 다양성 증대효과와 일치한다고 볼 수 있 다. 이와같은 결과는 복합미생물제제 처리구가 다른 처리구에 비해 높은 토양미생물 군집의 활성을 나타내어 고추의 근권과 상호작용을 하고 이것이 뿌리를 비롯한 고추의 생장촉진에 직/ 간접적으로 작용하여 결과적으로 고추생장촉진과 수확량 증대 효과가 나타날 수 있도록 영향을 주었다고 생각할 수 있다. 본 연구에 사용된 복합미생물제제는 토양미생물 생태의 다양성 증 대와 고추생장촉진의 두 목적을 동시에 이룰 수 있을 것으로 기대된다.

\section{초 록}

친환경 농법이 대두되면서 식물 병원균에 대한 길항능과 식물 생장 촉진능을 동시에 가지는 plant growth promoting rhizobacterium (PGRP)을 이용해 식물병을 방제하는 미생물 농 


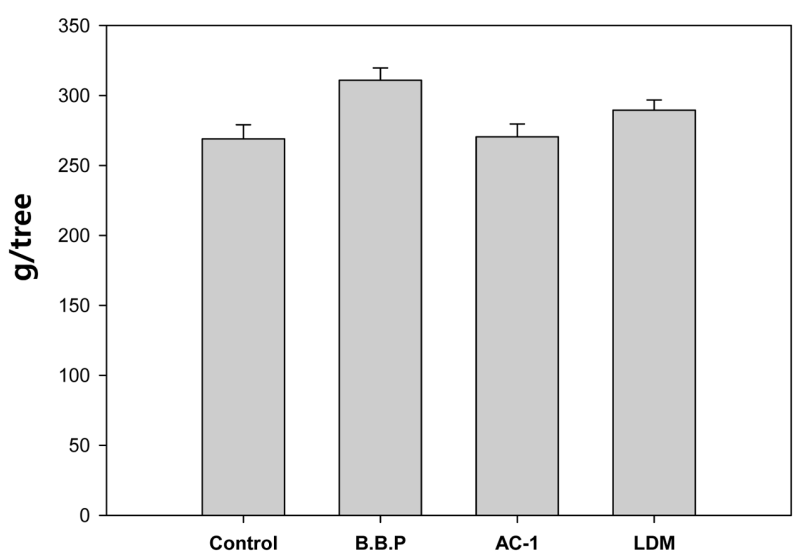

Fig. 3 Crop increasing of fresh weight of the red peppers by the treatment of the microbial consortium agent. Commercial bio-fungicide and microbial consortium agent was treated $10^{6}$ cells per plant. Values are expressed as the means of four replicates, each containing 50 plants. Fresh weight of the red pepper were measured by gram per a tree. Control, only water treatment; B.B.P, new microbial consortium agent; AC-1, commercial bio-fungicide; LDM, chemical pesticide.

법이 선호되고 있다. 본 연구에서는 토양비옥도 지표효소로 알 려진 5종의 토양효소활성 측정을 이용해 plant growth promoting rhizobacterium 균주인 Bacillus subtilis AH18, Bacillus licheniformis K11, Pseudomonas fluorescens 2112를 조합한 복 합미생물제제와 시판중인 미생물농약, 화학농약을 처리한 고추 경작지에서 토양미생물상을 분석하고 고추의 생장 및 수확량을 측정하여 메타지노믹스를 이용한 토양미생물 다양성 연구의 기 초자료로 사용하고자 하였다. 토양효소활성의 측정에서 복합미 생물제제 처리구가 dehydrogenase $3.5584 \mu \mathrm{g}$ TPF $\mathrm{g}^{-1} \mathrm{~h}^{-1}$, urease $15.8689 \mu \mathrm{g} \mathrm{NH}{ }_{4}^{-} \mathrm{N} \mathrm{g}^{-1} \mathrm{~h}^{-1}$, phosphatase $0.5692 \mu \mathrm{g}$ PNP $\mathrm{g}^{-1} \mathrm{~h}^{-1}, \quad \beta$-glucosidase $2.4785 \mu \mathrm{g} \quad \mathrm{PNP} \quad \mathrm{g}^{-1} \mathrm{~h}^{-1}$, cellulase $86.1597 \mu \mathrm{g}$ glucose $\mathrm{g}^{-1} \mathrm{~h}^{-1}$ 의 수치를 나타내 타처리구보다 높은 활성을 보여 토양미생물상의 다양성이 증대됨을 확인하였다. 또 한, 고추의 생장촉진도측정에서 복합미생물제제가 타처리구에 비해 주경장에서 최대 $6.1 \%$, 경경에서 최대 $8.1 \%$ 의 생장촉진 능을 보여 복합미생물제제의 생장촉진능을 확인하였다. 생고추 의 수확량 측정에서는 복합미생물제제가 무처리구를 기준으로 했을 때 $14 \%$ 의 수확량 증대효과를 나타내었고, 화학농약 처리 구보다도 $7.3 \%$ 의 증대효과를 나타내어 복합미생물제제에 의한 수확량 증대효과도 확인하였다. 따라서 본 연구에 사용된 복합 미생물컨소시움제제가 고추경작지 토양의 미생물상 다양성 증 가와 고추의 생장촉진 및 수확량 향상 모두에 기여함을 알 수 있었다.

Keywords: plant growth promoting rhizobacterium, soil enzyme, soil microbial community

감사의 글. 본 연구는 한국연구재단 기초연구사 (과제번호: 2010-0008216)의 지원에 의해 이루어진 것으로 이에 감사 드립니다.

\section{참고문헌}

Anderson JM (1991) The effects of climate change on decomposition processes in grassland and coniferous forests. Ecol Appl 1, 326-437.

Baek MH (2003) Assessment of soil environment risk with use of soil microbes at the undustrial complex. Graduate School, Sunchon National University, Suncheon, Korea.

Chew I, Obbard JP, and Stanforth RR (2001) Microbial cellulose decomposition in soils from a rifle range contaminated with heavy metals. Env Sci 111, 367-375.

Choi MY (2003) Microbial diversity on an industrialized and agricultural district. Graduate School, Yosu National University, Yosu, Korea.

Debosz K, Rasmussen PH, and Pedersen AR (1999) Temporal variations in microbial biomass $\mathrm{C}$ and cellulolytic enzyme activity in arable soils effects of organic matter input. Appl Soil Ecol 13, 209-218.

Eivazi F and Tabatabai MA (1988) Glucosidases and agalactosidases in soils. Soil Biol Biochem 20, 601-606.

Garcia C and Hernandez T (1997) Biological and biochemical indicators in derelict soils subject to erosion. Soil Biol Biochem 29, 171-177.

Garcia-Gil JC, Plaza P, Soler-Rovira P, and Polo A (2000) Long-term effects on municipal solid waste compost application on soil enzyme activities and microbial biomass. Soil Biol Biochem 32, 1907-1913.

Han KH, Lee CU, and Kim SD (1999) Antagonistic role of chitinase and antibiotic produced by Promicromonospora sp. KH-28 toward $F$. oxysporum. Korean J Appl Microbial Biotechnol 27, 349-353.

Hu C and Cao Z (2007) Size and activity of the soil microbial biomass and soil enzyme activity in long-term field experiments. World J Agri Sci 3, 63-70.

Jeong DH, Park KD, Kim SH, Kim KR, Choi SW, Kim JT, Choi KH, and Kim JH (2004) Identification of Streptomyces sp. producing antibiotics against phytopathogenic fungi, and its structure. J Microbiol Biotechnol 14, 212-215.

Joa JH, Lee JH, Won HY, Han SG, and Lim HC (2008) Effect of different soil managements on physical properties and microbial activities in citrus orchard soil. Korean J Soil Sci Fert 41, 279-284.

Joa JH, Moon DG, Chun SJ, Kim CH, Choi KS, Hyun HN, and Kang UG (2009) Effect of temperature on soil microbial biomass, enzyme activities, and PLFA content during incubation peroid of soil treated with organic materials. Korean J Soil Sci Fert 42, 500-512.

Jung HK and Kim SD (2004) Selection and antaginistic mechanism of Pseudomonas fluorescens 4059 against phytophthora blight disease. Korean J Microbiol Biotechnol 32, 312-316.

Jung HK, Kim JR, Woo SM, and Kim SD (2006) An auxin producing plant growth promoting rhizobacterium Bacillus subtilis AH18 which has siderophore-producing biocontol activity. Korean J Microbiol Biotechnol 34, 94-100.

Jung HK, Kim JR, Woo SM, and Kim SD (2007) Selection of the auxin, siderophore, and cellulase-producing PGPR, Bacillus licheniformis K11 and its plant growth promoting mechanisms. J Korean Soc Appl Biol Chem 50, 23-28.

Jung HK, Ryoo JC, and Kim SD (2005) A multimicrobial biofungicide for the biological control against several important plant pathogenic fungi. $J$ Korean Soc Appl Biol Chem 48, 40-47.

Kang SJ, Kim JH, and Joo GJ (2005) Isolation of antagonistic bacteria against Fusarium oxysporum and physicochemical properties of compost mixed with microbial formulation. Korean J Hort Sci Technol 23, 342-350.

Kim KY and Kim SD (1997) Biological control of Pyricularia aryzae blast spot with the antibiotic substances produced by Bacillus sp. KL-3. Korean J Appl Microbiol Biotechnol 25, 396-402.

Kirschbaum MUF (1995) The temperature dependence of soil organic matter decomposition, and the effect of global warming on soil organic $\mathrm{C}$ storage. Soil Biol Biochem 31, 205-211.

Koch O, Tscherko D, and Kandeler E (2007) Temperature sensitivity of microbial respiration, nitrogen mineralization, and potential soil enzyme activities in organic alpine soils. Glob Biogeochem Cycles 21, GB4017.

Kwon YT (2008) Capsicum annuum manual. Yeongyang-gun Agriculture Extension Center, Korea.

Langer U and Günther Th (2001) Effects of alkaline dust deposits from phosphate fertilizer production on microbial biomass and enzyme activities in grassland soils. Env Pollution 112, 321-327.

Lee ET and Kim SD (2000) Selection and antifungal activity of antagonistic 
bacterium Pseudomonas sp. 2112 against red-pepper rotting Phytophthora capsici. Korean J Appl Microbiol Biotechnol 28, 334-340.

Lee JM, Do ES, Baik SB, and Chun SC (2003) Effect of organic amendments on efficacy of biological control of seedling damping-off of cucumber with several microbial products. Korean J Mycol 31, 44-49.

Lim HS and Kim SD (1995) The role and characterization of $\beta$-1,3-glucanase in biocontrol of Fusarium solani by Pseudomonas stutzeri. J Microbiol 33, 295-304.

Lim JH, Jung HY, and Kim SD (2009) Development of the microbial consortium for the environmental friendly agriculture by the antagonistic rhizobacteria. J Appl Biol Chem 52, 116-120.

Nobili DM, Contin M, and Brookes PC (2006) Microbial biomass dynamics in recently air-dry for up to 103 years. Soil Biol Biochem 38, 2871-2881.

Pancholy SK and Rice EL (1973) Soil enzymes in relation to old field succession: amylase, cellulase, invertase, dehydrogenase and urease. Soil Sci Soc Am Proc 37, 47-50.

Park KC, Lim JH, Kim SD, and Yi YK (2009) Effects of phytophthora blightantagonistic Microorganisms Bacillus subtilis AH18 and Bacillus licheniformis $\mathrm{K} 11$ on the soil microbail community. J Appl Biol Chem 52, 121-125.

Paul EA and Clark FE (1989) Soil microbiology and biochemistry. Academic press, San Diego, CA.

Pusey PL (1996) Micro-organism as agents in plant disease control. Crop Protection Agents from Nature: Natural Products and Analogues. Crit
Rep Appl Chem 35, 426-436.

Rai B and Srivastava AK (1983) Decomposition and competitive colonization litter by fungi. Soil Biol Biochem 15, 115-117.

Ross DJ (1970) Effects of storage on dehydrogenase activity of soils. Soil Biol Biochem 2, 55-61.

Sardans J, Penuelas J, and Estiarte M (2008) Changes in soil enzymes related to $\mathrm{C}$ and $\mathrm{N}$ cycle and in soil $\mathrm{C}$ and $\mathrm{N}$ content under prolonged warming and drought in a Mediterranean shrubland. Appl Soil Ecol 39, 223-235.

Speir TW, Kettles HA, Percival HJ, and Parshotam A (1999) Is soil acidification the cause of biochemical responses when soils are amended with heavy metal salts? Soil Biol Biochem 31, 1953-1961.

Thirup L, Johansen A, and Winding A (2003) Microbial succession in the rhizosphere of live and decomposing barley roots as affected by the antagonistic strain Pseudomonas fluorescens DR54-BN14 or the fungicide imazalil. FEMS Microb Ecol 43, 383-392.

Trevors JT, Mayfield CI, and Inniss WE (1982) Measurement of electron transport system (ETS) activity in soil. Microb Ecol 8, 163-168.

Trevors JT (1984) Dehydrogenase activity in soil: A comparison between the INT and TTC assay. Soil Biol Biochem 16, 673-674.

Van Veen JA, Van Overbeek LS, and Van Elsas JD (1997) Fate and activity of microorganism introduced into soil. Microbiol Mol Rev 61, 121-135.

Yun GH, Lee ET, and Kim SD (2001) Identification and antifungal antagonism of Chryseomonas luteola 5042 against Phytophthora capsici. Korean J Appl Microbial Biotechnol 29, 186-193. 